\title{
Physiological quality of Erythrina velutina Willd. seeds (FABACEAE) under different storage conditions
}

\author{
Qualidade fisiológica de sementes de Erythrina velutina Willd. \\ (FABACEAE) em diferentes condições de armazenamento
}

\author{
Renata Conduru Ribeiro', Samara Elizabeth Vieira Gomes ${ }^{1}$ \\ and Bárbara França Dantas ${ }^{1}$
}

\begin{abstract}
RESUMO
O objetivo nesse trabalho foi avaliar o efeito de diferentes embalagens e ambientes de armazenamento para manutenção da qualidade fisiológica das sementes de Erythrina velutina Willd. (mulungu). As sementes de E. velutina foram coletadas, beneficiadas e acondicionadas em embalagens de papel Kraft ou plástico transparente e armazenadas a temperatura ambiente $\left(30 \pm 5^{\circ} \mathrm{C}, 56 \pm 6 \%\right.$ UR) e em câmara fria $\left(10 \pm 2{ }^{\circ} \mathrm{C}, 74 \pm 4 \%\right.$ UR), por um período de até 420 dias. As sementes recém colhidas e as armazenadas por 90, 210, 300 e 420 dias foram avaliadas quanto a teor de água, germinação e de vigor de plântulas. Observou-se que o teor de água das sementes de mulungu foi alterado com o tempo de armazenamento e o tipo de embalagem utilizada. A germinação não foi afetada durante o período de armazenamento para todos os ambientes e embalagens, no entanto, não significou com isto o sucesso no vigor das plântulas ou seja, maior crescimento e acúmulo de biomassa seca. Mesmo ocorrendo a diminuição no vigor das plântulas, com o tempo de armazenamento, em temperatura ambiente, sacos de papel e plásticos até 420 dias, proporcionou uma melhor manutenção da qualidade das sementes de mulungu.
\end{abstract}

Palavras chave: vigor, mulungu, ambientes.

\begin{abstract}
The objetive of this work was to evaluate the effect of different bags and storage environments in maintaining the physiological quality of Erythrina velutina Willd. (mulungu) seeds. E. velutina seeds were collected, processed and placed in Kraft paper and transparent plastic bags, and stored at room temperature $\left(30 \pm 5{ }^{\circ} \mathrm{C}, 56 \pm 6 \% \mathrm{RH}\right)$ and cold chamber $\left(10 \pm 2{ }^{\circ} \mathrm{C}, 74 \pm 4 \% \mathrm{RH}\right)$ for up to 420 days. Recently harvested seeds and the ones stored for $90,210,300$ and 420 days were evaluated for water content, germination and seedling vigor. It was observed that the water content of mulungu seeds was altered by storage periods and bagging; germination was not affected during the evaluation period for all environments and bagging. However, this did not mean successful seedling vigor or higher growth and dry biomass accumulation. Even with the decrease in seedling vigor according to storage time, in room temperature, in paper and plastic bags up to 420 days provided a better maintenance of the quality of mulungu seeds.
\end{abstract}

Keywords: vigor, mulungu, enviroments.

\section{INTRODUCTION}

Erythrina velutina Willd. belongs to the Fabaceae family and is commonly known as mulungu, among other names (LORENZI; MATOS, 2008). It has great economic importance, its flowering has high ornamental potential and it is used in the afforestation of streets and gardens; It is a tree that can be found in the semi-arid of northeaste of Brazil region, characterized as quite drought-resistant, with quick growth and nitrogen fixing capacity, thus, it is used in the recovery of degraded areas (LORENZI; MATOS, 2008; MELO; CUNHA, 2008; MATHEUS; LOPES, 2009).

One of the aspects currently studied about these seeds is their physiological quality, since they are subject to different alterations that may affect their vigor. The changes can be of physiological,

1. Empresa Brasileira de Pesquisa Agropecuária, Embrapa. Petrolina / PE, Brazil. E-mail: rconduru@gmail.com

Sci. For., Piracicaba, v. 46, n. 120, p. 562-570, dez. 2018

DOI: dx.doi.org/10.18671/scifor.v46n120.05 
biochemical and physical and they occur after seed ripeness, in this way, studies of the physiological processes of seeds are the starting point for the rational use and exploitation of native Caatinga species. (GUEDES et al., 2010).

Normally, the seeds are not used immediately after harvested. Therefore, they should be stored for future use in the same year or even the following years, since the native species present seed production cyclicity, characterized by one year of high production, followed by one or two low yield (KISSMANN et al., 2009).

The storage is an important method to maintain the longevity of seeds, obtained through the preservation of the physical, physiological and sanitary quality until future sowing (PARRELLA, 2011). Seed storage may be influenced by various factors, such as: initial seed quality, climate conditions during ripening, ripeness degree at the time of the harvest, water content, degree of mechanical injury, packaging and characteristics of the environment (CARVALHO; NAKAGAWA, 2012).

Among the factors affecting seed quality during storage, it is possible to highlight environmental temperature and seeds water content. Storing seeds at a proper temperature and relative air humidity conditions helps maintaining their physiological potential, it reduces the respiratory process and therefore decreases their deterioration process (CARVALHO; NAKAGAWA, 2012; MARCOS-FILHO, 2015). The effects of these factors over seed performance during storage, depend on the characteristics of the species and the conditions and packaging used during storage.

Among the storage environments, it is possible to highlight the natural and low refrigeration environment, cold, dry and cold-dry chambers; the latter may be controlled in different situations (PARRELLA, 2011). As for the packaging used in storage, various aspects must be considered while choosing, such as the climate conditions that seeds will endure during the process and the seed water content control: in this regard, the characteristics of the packaging must help reducing the speed of the deterioration process (CARVALHO; NAKAGAWA, 2012).

However, due to the economic importance, and the ornamental and medical potential of E. velutina, it is necessary to focus on the evaluation of its physiological potential, highlighting the studies about storage under other conditions that could be accessible to small producers for a longer period, for seeds from this species. In order to contribute to the establishment of methods to preserve E. velutina seeds, this work was conducted with the objective to evaluate the physiological quality of seeds, submitted to different conditions and storage periods, since the correct identification of the storage behavior of seeds is fundamental to choose the conservation strategy.

\section{MATERIAL AND METHODS}

\section{Seed acquisition and storage}

E. velutina seeds were harvested in October 2008, directly from the parent trees, located in the city of Jutaí, Lagoa Grande - Pernambuco state (37 18'03" W, 90 52' 92" S) .

After harvesting, fruits were taken to the laboratory to be processed manually by removing seeds from dry pods, after that, the seeds were homogenized and samples placed in four different conditions such as: Kraft paper ( $100 \mathrm{~g} / \mathrm{m}^{2}$ grammage $)$ and transparent plastic $(0.15 \mathrm{~mm}$ thickness $)$ bags, and they were later stored at room temperature $\left(30 \pm 5^{\circ} \mathrm{C}, 56 \pm 6 \% \mathrm{RH}\right)$ and in a cold chamber $\left(10 \pm 2{ }^{\circ} \mathrm{C}, 74 \pm 4 \% \mathrm{RH}\right)$, for up to 14 months. In recently harvested seeds and after 90, 210, 300 and 420 days, samples were removed from each bag and storage environment to evaluate water content, germination and vigor.

The experimental design was completely randomized, with treatments distributed in a factorial scheme $1+4 \times 4$, represented by fresh seeds + four storage periods $\mathrm{x}$ four storage conditions (two environments combined with two packagings).

\section{Water content (WC)}

The WC was measured using four sub-samples with 25 seeds placed inside aluminum capsules in an oven at $105 \pm 3{ }^{\circ} \mathrm{C}$ for 24 hours, and the results were expressed in percentage (BRASIL, 2009). 
Ribeiro et al. - Physiological quality of Erythrina velutina Willd. seeds

(FABACEAE) seeds under different storage conditions

\section{Germination test}

For the germination test, four replications with 25 seeds were used, which were previously scarified in the opposite region from the micropyle, with a mini circular saw with the assistance of a mini-rotary tool (Western R-40) to overcome the integumentary dormancy; subsequently, the scarified seeds were submitted to asepsis using a sodium hypochlorite (2\%) solution, for 2 minutes, and they were later washed in distilled water and placed to germinate on a substrate of germitest paper roll, dampened with distilled water in a quantity equivalent to 2.5 times the weight of the dry paper, adapted from Brazil (2013). Rolls containing the seeds were incubated in BOD-type germinators adjusted to the constant temperature of $25^{\circ} \mathrm{C}$, photoperiod of 12 hours, for 10 days in a row. The evaluation was performed daily, considering as "germinated" the seeds that sprouted a radicle that was at least $2 \mathrm{~mm}$ long.

The evaluated variables were: germination percentage (G\%), mean time (MGT) (LABOURIAU, 1983), mean speed (MGS) (KOTOWISKI, 1926), germination speed index (GSI) (MAGUIRE, 1962) and coefficient of uniformity of germination (CUG) (HEYDECKER, 1973).

\section{Vigor test - Seedling Growth}

The seedling growth evaluation was performed with four replications of 10 seeds, which were distributed on a line drawn on the upper third, in the longitudinal direction of the germitest paper, dampened with distilled water at a volume corresponding to 2.5 times the paper weight. Seeds were placed with the radicle edge facing the lower side of the paper. Rolls similar to the ones from the germination test were prepared (BRAZIL 2013) and the four replications (four rolls) were grouped, sealed in plastic bags and placed vertically, so that gravitropism would happen naturally and help evaluating the seedlings, inside a BOD type germinator at the constant temperature of $25^{\circ} \mathrm{C}$ and photoperiod of $12 \mathrm{~h}$ (NAKAGAWA, 1999). At the end of 10 days, germination was evaluated (formed seedlings) and the shoot (SL) and main root (RL) length were measured. Starting from these evaluations, it was possible to obtain a value represented by the sum of the verified lengths, regardless of the seedling classification, and the total number of seedlings from each replication.

After removing cotyledons, the fresh biomass of shoot (SFB) and roots (RFB) of the seedlings from each replication was determined. After the initial weighing, they were placed in Kraft paper bags and put to dry in a forced air circulation oven at $70^{\circ} \mathrm{C}$, for 48 hours. Samples were removed from the oven at the end of this period, placed in a desiccator and they were subsequently weighed in order to determine the total dry biomass of shoot (SDB) and roots (RDB) of the seedlings from the replication.

\section{Statistical analysis}

Data obtained were submitted analysis of variance, using the software Assistat (SILVA; AZEVEDO, 2016). Percentage data were transformed by the function $(x+0.5)^{0.5}$. In order to adjust the regression equations, a significant model presenting the highest determination coefficient was selected.

\section{RESULTS AND DISCUSSION}

There was interaction between months and storage type for $\mathrm{WC}$, mean germination time (MGT), mean germination speed (MGS), germination speed index (GSI), RL and RDB (Table 1). The interaction between seeds stored under different conditions and recently harvested seeds presented significant results for all variables, except for germination percentage (G\%) and shoot fresh biomass (SFB).

There was no significant effect in relation to the different storage months for the variables root length (RL) and root fresh biomass (RFB). As for storing, there were significant differences only for WC, root length (RL) and root dry biomass (RDB) (Table 1). 
Table 1. Summary of the analysis of variance, by mean square, referring to the values of water content (WC), germination percentage (G\%), mean germination time (MGT), mean germination speed (MGS), germination speed index (GSI), coefficient of uniformity of germination (CUG), shoot length (SL) and root length (RL), shoot fresh biomass (SFB) and root fresh biomass (RFB), shoot dry biomass (SDB) and root dry biomass (RDB) of Erytrhina velutina stored seeds (SS), recently harvested fresh seeds (FS) and variation coefficient $(\mathrm{CV} \%)$.

Tabela 1. Resumo da análise de variância, pelo quadrado médio, referentes aos valores de teor de água (WC), porcentagem de germinação (G\%), tempo médio de germinação (MGT), velocidade média de germinação (MGS), velocidade de germinação (GSI), coeficiente de uniformidade de germinação (CUG) crescimento da parte aérea (SL) e raiz (RL), biomassa fresca da parte aérea (SFB) e da raiz (RFB), biomassa seca da parte aérea (SDB) e raiz (RDB), de sementes recém-coletadas (FS) e armazenadas (SS) em diferentes condições de Erytrhina velutina e o coeficiente de variação (CV\%).

\begin{tabular}{|c|c|c|c|c|c|}
\hline $\begin{array}{l}\text { Source of } \\
\text { Variation }\end{array}$ & $\begin{array}{l}\text { Months of storage } \\
\text { (M) }\end{array}$ & $\begin{array}{l}\text { Storage condition } \\
\text { (C) }\end{array}$ & $M^{*} C$ & SS*FS & CV\% \\
\hline WC & $3,25281^{* *}$ & $1,28779^{*}$ & $0,77336^{*}$ & $3,89540^{* *}$ & 6,81 \\
\hline G\% & $0,00007^{* *}$ & $0,00001^{\mathrm{ns}}$ & $0,00001^{\mathrm{ns}}$ & $0,00001^{\mathrm{ns}}$ & 0,56 \\
\hline MGT & $1,71944^{\star *}$ & $0,17956^{\mathrm{ns}}$ & $0,24358^{* *}$ & $5,65029^{* *}$ & 7,16 \\
\hline MGS & $0,00832^{* *}$ & $0,00081^{\mathrm{ns}}$ & $0,00116^{* *}$ & $0,01471^{* *}$ & 6,97 \\
\hline GSI & $24,19309^{* *}$ & $0,34088^{\mathrm{ns}}$ & $0,67459^{* *}$ & $5,82232^{* *}$ & 7,06 \\
\hline CUG & $1,19300^{*}$ & $0,62613^{\text {ns }}$ & $0,46633^{\mathrm{ns}}$ & $2,90869^{* *}$ & 51,74 \\
\hline SL & $5,65534^{*}$ & $0,64604^{\mathrm{ns}}$ & $3,43530^{\mathrm{ns}}$ & $16,89516^{\star *}$ & 24,94 \\
\hline $\mathrm{RL}$ & $8,77108^{\mathrm{ns}}$ & $14,96246^{* *}$ & $11,77948^{* *}$ & $16,98750^{*}$ & 20,81 \\
\hline SFB & $10,61155^{* *}$ & $2,16213^{\mathrm{ns}}$ & $2,42213^{\mathrm{ns}}$ & $7,34526^{\mathrm{ns}}$ & 27,68 \\
\hline RFB & $0,94628^{\mathrm{ns}}$ & $0,99858^{\mathrm{ns}}$ & $0,70322^{\mathrm{ns}}$ & $25,59645^{\star *}$ & 28,28 \\
\hline SDB & $0,03941^{*}$ & $0,01209^{n s}$ & $0,01343^{\mathrm{ns}}$ & $0,40121^{* *}$ & 24,63 \\
\hline RDB & $0,00758^{* *}$ & $0,00717^{*}$ & $0,00547^{* *}$ & $0,05874^{* *}$ & 19.01 \\
\hline
\end{tabular}

ns; *; ** $=$ non significant, significant at $5 \%$ and at $1 \%$, respectively by Tukey test.

The initial WC of recently harvested Erythrina velutina seeds was $6.35 \%$. These seeds are classified as orthodox, which may endure dehydration up to around 5\% (BEWLEY et al., 2013). The tegument of E. velutina seeds present low water permeability, which blocks the exchange of the seed moisture with the environment. However, considering the initial and final storage period, regardless of packaging and environments, there was an increase in WC of the stored seeds around 3\%, demonstrating that the packaging used allowed an increase in WC of seeds from 6.35 to $9.56 \%$. The WC of seeds placed in paper bags, at the end of the 14-month storage period, was $8.83 \%$ at room temperature and $9.56 \%$ in cold chamber; these were the highest values presented by E. velutina seeds (Figure 1a).

The knowledge seeds WC allows choosing the most appropriate procedures from harvest to storage, which enables preserving physical, physiological and sanitary quality, as well as allowing problem identification and adoption of proper solution measures (MARCOS-FILHO, 2015).

According to Reis et al. (2012), plastic packaging acts as a barrier in protecting seeds during storage, maintaining the initial WC of seeds, with the intent to reducing respiration and thus diminishing the speed of the deterioration process. In Amburana cearensis (Allemao) A. C. Sm. seeds, plastic bags reduced the gas exchange between seeds and the environment where they were stored (LUCIO et al., 2016).

The G\% of seeds remained high during all analyzed months, with no statistical differences between analyses. These results highlight that this species remains viable and with high germination up to 14 months, when stored in paper or plastic packaging and kept in laboratory environment and cold chamber (Figure 1b).

Silva et al. (2011), working with the storage of E. velutina for about 8 months, observed that none of the used conditions for storage caused significant vigor losses, despite the fabric and paper packaging resulted in less satisfactory results for the emergence of seedlings than this work. According to the same authors, these results must be probably due to the deterioration of seeds by oxidation, since, despite the fact that the WC did not change, it was enough to allow higher respiration (SILVA et al., 2011).

In this work, it was possible to verify that impermeable packaging allowed changes in the WC; however, only starting from the 14th storage month, it was possible to verify alterations in the seed vigor. This result may be attributed to the fact that the sensitivity to the deterioration process of seeds may vary, and seeds from the same species from different regions may present different levels of desiccation tolerance. Recent works indicate that the place of origin of these seeds has a significant effect on their development and in the degree of desiccation tolerance that may be acquired by the 


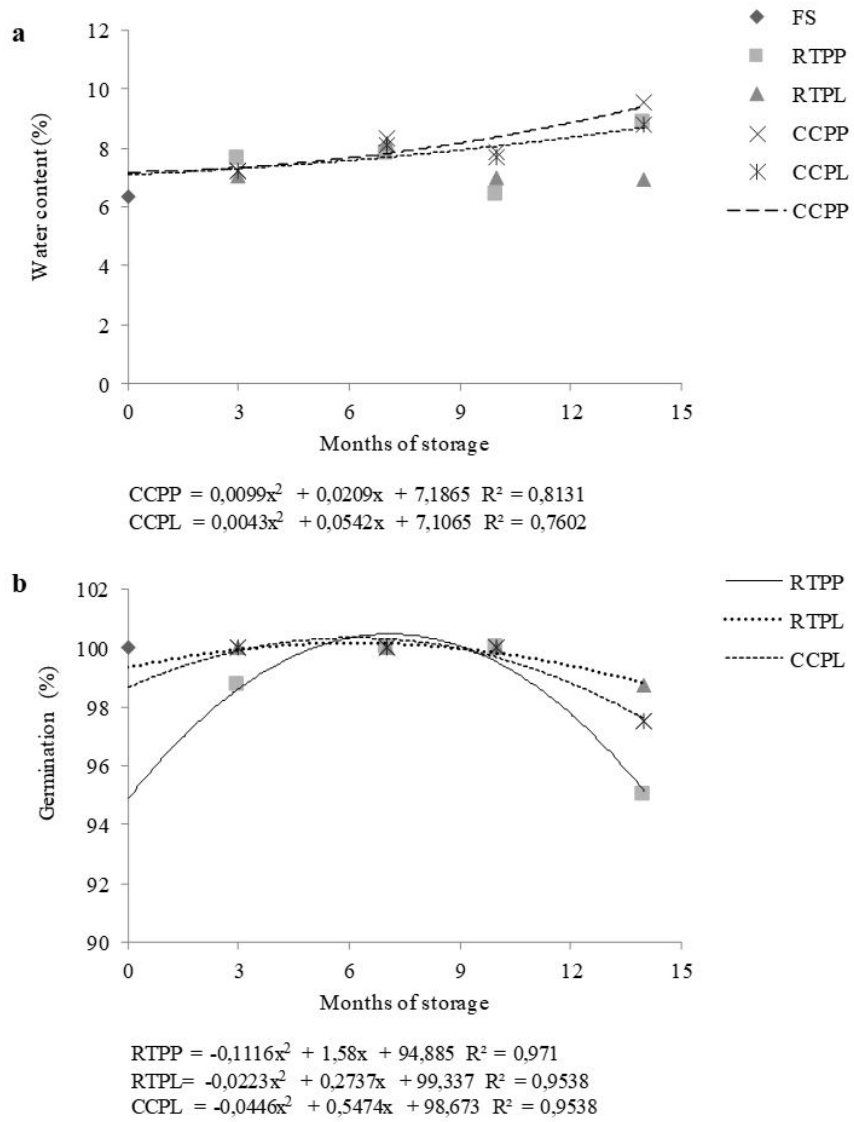

Figure 1. Water content (WC- a) and Germination percentage (G- b) of Erythrina velutina seeds stored at different conditions. FS - fresh seeds, recently harvested. RTPP - room temperature in paper bag, RTPL - room temperature in plastic bag, CCPP - cold chamber in paper bag, CCPL - cold chamber in plastic bag.

Figura 1. Teor de água (WC- a) e porcentagem de germinação (G- b) de sementes de Erytrhina velutina em diferentes condições de armazenamentos. FS- sementes frescas, recém-coletadas. RTPP- temperatura ambiente em saco de papel, RTPL- temperatura ambiente em saco plástico, CCPP- câmara fria em saco de papel, CCPL- câmara fria em saco de plástico.

species (PRITCHARD et al., 2014). In addition, there is the genetic variability, which causes difference among the species and the individual variations among seeds from the same lot (SANTOS et al., 2009).

The initial MGT before storage for recently harvested seeds was 5.11 days; however, along the storage period there was a decrease initially in the needed time for the germination process to occur (Figure 2a), going from an average of 3.5 days ( 3 and 7 months) and a increase to about 4 days (10 and 14 months).

The MGT gives a kinetic character to the germination process, demonstrated by the seed vigor (FERREIRA; BORGHETTI, 2004). The behavior demonstrated by orthodox mulungu seeds during the experiment demonstrates that they may remain viable for a long time.

The MGS of E. velutina seeds differed between time and storage conditions. In the seventh month of storage, seeds presented higher MGS, at room temperature and plastic ( 0.31 days $\left.^{-1}\right)$ and paper bags (Figure 2b). Starting from the tenth month, there was a decrease in the MS (0.25-0.24 days $\left.{ }^{-1}\right)$, mainly for seeds stored in impermeable packaging; however, these values are even higher, compared to the MGS of recently harvested seeds $\left(0.19\right.$ days $\left.^{-1}\right)$.

The vigor determined by GSI and CUG of E. velutina seeds presented on figure $2 \mathrm{c}-\mathrm{d}$ increased at the 7th storage months with all packaging types. Among the tested environments and packaging, room temperature and paper bags were the ones obtaining the highest values in the two parameters at the 7th month, namely 8.26 seedl./day (GSI) and 2.16 day $^{-2}$ (CUG) (Figure 2c-d). This result may be attributed to the increase in WC of about $2 \%$ at the 7 th month; thus, a lower water quantity was required to complete the germination process, helping GSI and CUG.

Alterations in the WC of E. velutina seeds enabled an improvement in the germination process; these changes, up to the period of 7 storage months, were not enough to cause deterioration reactions when compared to 14 months, when it was possible to observe signs of reduction in the physiological quality, compared to the previous months (Figure 2c-d). 
a

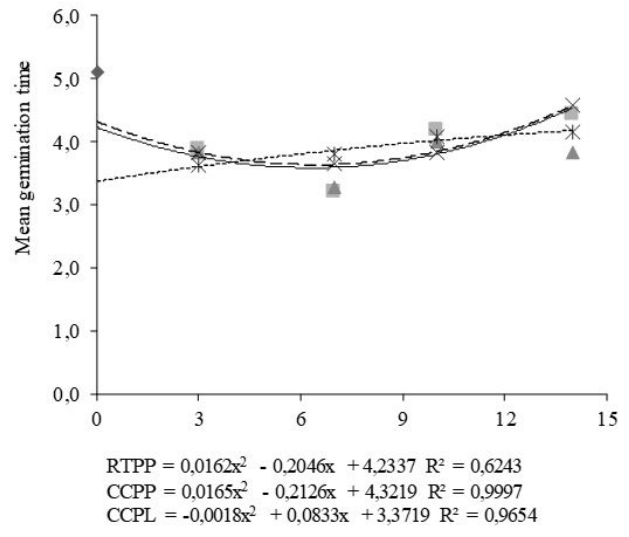

c

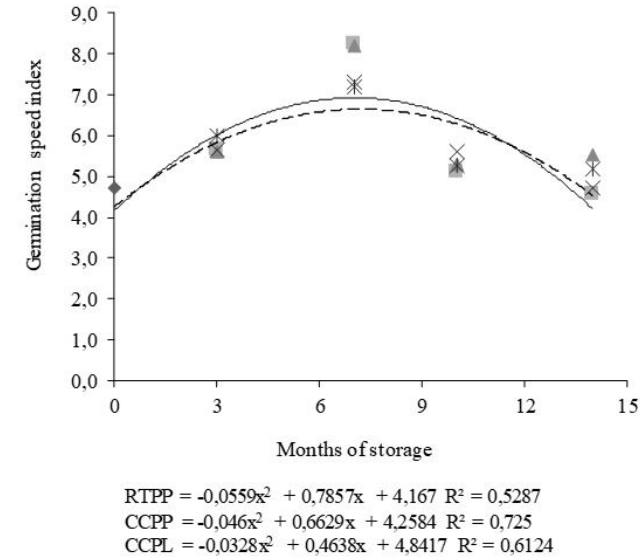

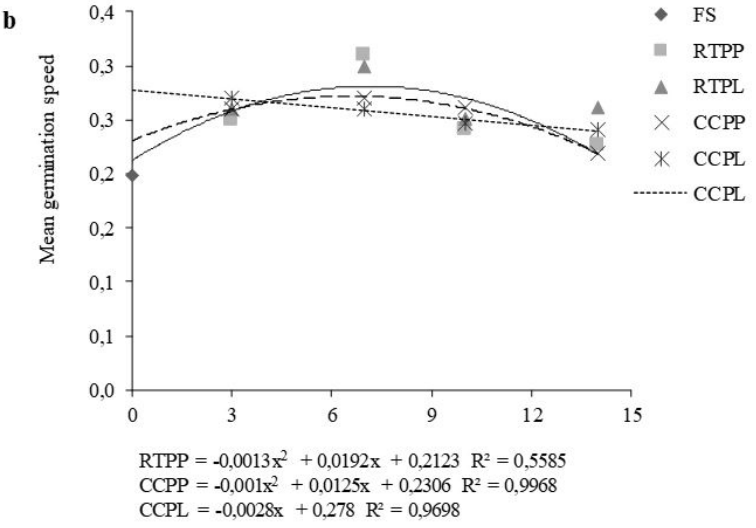

d

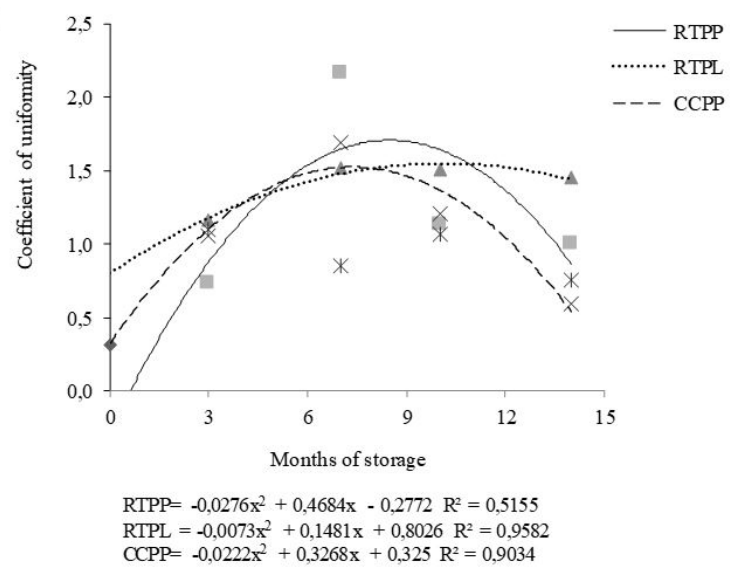

Figure 2. Mean germination time (MGT, day)-a, mean germination speed (MGS, day $\left.{ }^{-1}\right)-b$, germination speed index (GSI, seedling day ${ }^{-1}$ )-c and coefficient of uniformity of germination (CUG, day ${ }^{-2}$ )-d of Erythrina velutina seeds stored at different conditions. FS - fresh seeds, recently harvested. RTPP - room temperature in paper bag, RTPL - room temperature in plastic bag, CCPP - cold chamber in paper bag, CCPL - cold chamber in plastic bag.

Figura 2. Tempo Médio de germinação (MGT, dia)-a, Velocidade Média de germinação (MGS, dia-1)-b, Velocidade de Germinação (GSI, plântula dia ${ }^{-1}$ )-c e Coeficiente de uniformidade de Germinação (CUG, dia-2)-d de sementes de Erytrhina velutina em diferentes armazenamentos. FS- sementes frescas, recém-coletadas. RTPP- temperatura ambiente em saco de papel, RTPL- temperatura ambiente em saco plástico, CCPP- câmara fria em saco de papel- câmara fria em saco de plástico.

After reaching their physiological maturity, seeds gradually lose their vigor. The seed deterioration process is irreparable, but may be delayed, depending on the considered species, the seed chemical composition, conditions under which they were produced and stored (CARDOSO et al., 2012).

Seeds from different species present different chemical constitutions, thus, the different reserve components synthesized and accumulated during the formation process, such as proteins, carbohydrates (especially starch) and lipids, influence directly the storage potential of these seeds (GRAHAM, 2008). Seeds with high oil content present lower storage potential compared to those with starch reserves, due to the lower chemical stability of lipids in relation to starch (BALEŠEVIĆ-TUBIĆ et al., 2010). Knowledge about the storage capacity of the seeds allows the adoption of appropriate conditions for each species and using this information to preserve biodiversity.

Seeds of E. velutina demonstrate long natural longevity of the seeds, being able to be linked to the great amount of reserve substances stored in the seed and the high content of proteins and sugars in their chemical composition (RIBEIRO et al., 2017).

The SL and RL of the seedlings decreased along the storage period, when compared to the growth in the initial period. There was no significant difference among the months for RL, despite the fact that in the 7th month, at room temperature and with plastic bags, growth exceeded $(13.01 \mathrm{~cm})$ the value found in the initial month $(10.98 \mathrm{~cm})$, (Figure $3 \mathrm{~b})$. The SL also presented the highest values at the 7 th storage month, at room temperature and in plastic bags $(6.50 \mathrm{~cm})$; however, they were lower than the value from the initial month $(7.20 \mathrm{~cm})$ (Figure $3 \mathrm{a}$ ). 

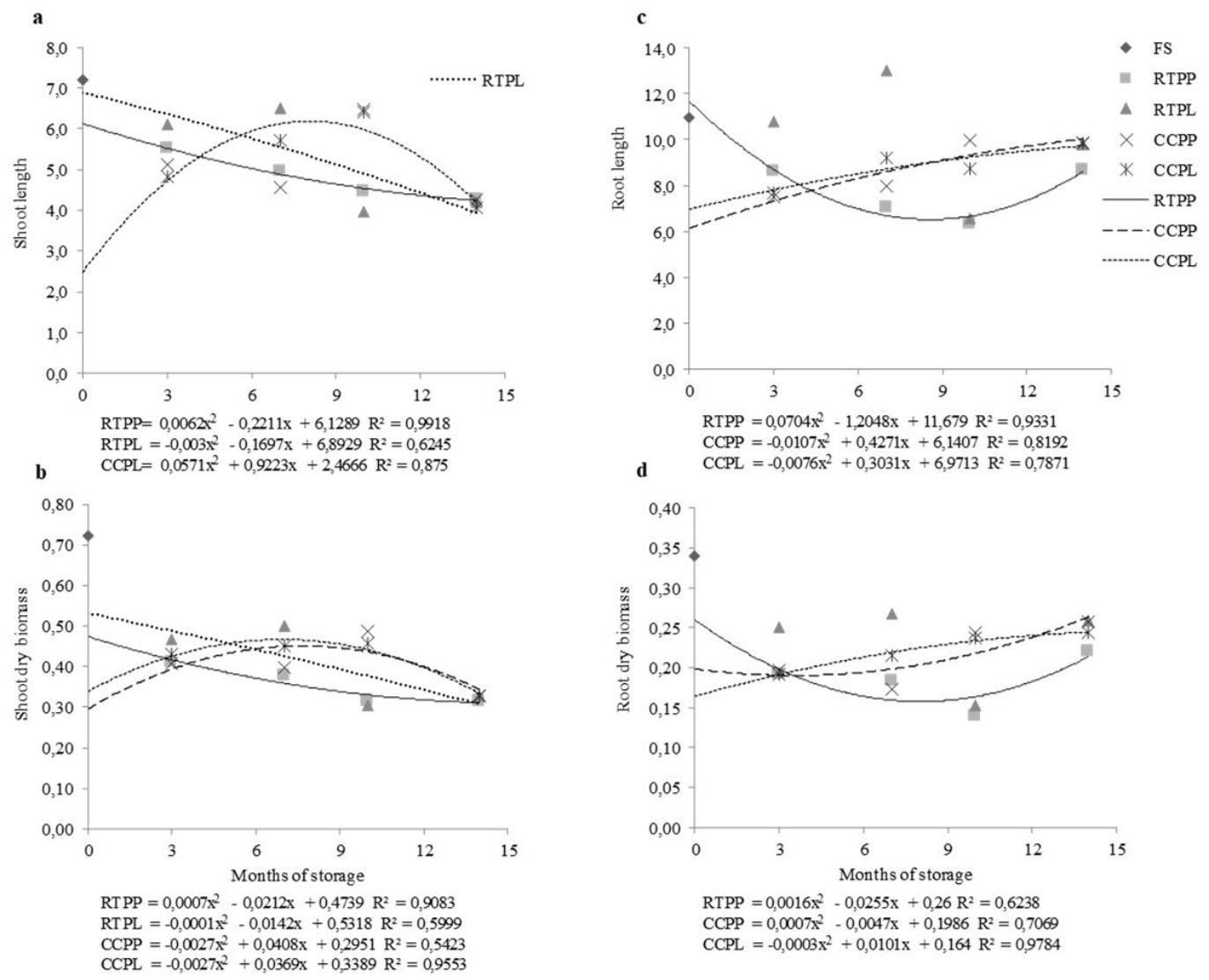

Figure 3. Shoot length ( $S L, c m$ )- $a$, shoot dry biomass (SDB, g)-b and shoot root dry biomass (RDB, g)-c root length and d root dry biomass of Erythrina velutina seedlings, after seed storage at different conditions. FS - fresh seeds, recently harvested, RTPP - room temperature in paper bag, RTPL - room temperature in plastic bag, CCPP - cold chamber in paper bag, CCPL - cold chamber in plastic bag.

Figura 3. Crescimento da parte aérea ( $S L, c m)$-a, Biomassa Seca da parte aérea (SDB, g)-b e biomassa seca de raiz (RDB, g)-c de sementes de Erytrhina velutina em diferentes armazenamentos. FS sementes frescas, recém coletadas, RTPP- temperatura ambiente em saco de papel, RTPL- temperatura ambiente em saco plástico, CCPP- câmara fria em saco de papel, CCPL- câmara fria em saco de plástico.

Comparing the two packagings, it was possible to observe that seeds placed on paper produced seedlings with lower SL and RL, at beginning and end of storage (Figure 3a-b). Silva et al. (2011), while analyzing different lots of E. velutina, observed that the best length value of the primary root of seedlings $(14.08 \mathrm{~cm})$ from the different storage environments on paper, fabric or glass, was obtained with the ones that remained in the refrigerator for 112 days, whereas the roots of seedlings from seeds stored in laboratory had their maximum length $(11.18 \mathrm{~cm})$ on day 81 , not presenting significant losses in the vigor of the seedlings from these seeds.

According to the adjusted curves for SDB and RDB, data revealed, in the regression analysis, quadratic effect on the seeds placed in the two packagings (paper and plastic) in the environment and cold chamber environments. It is possible to observe, under these storage conditions, that seeds had a similar behavior among themselves starting from the 3th storage month, with vigor values influenced by the storage periods; the plastic packaging outstood, with seeds appearing more vigorous (Figures 3c-d).

The SDB in the initial month had the biomass of $0.72 \mathrm{~g}$; the other months, with all packagings and storages varied from 0.30 to $0.50 \mathrm{~g}$, obtaining significant differences only for the storage months, when compared to recently harvested seeds, where it is possible to observe a decrease in vigor (Figure 3c). RDB in the initial month was $0.34 \mathrm{~g}$; none of the tested storages and packaging was able to obtain a similar biomass to the initial one. The lowest biomass was in the 7 th storage month, in the laboratory environment and with plastic $(0.15 \mathrm{~g})$ and paper $(0.14 \mathrm{~g})$ packaging; the other months varied from 0.19 to $0.24 \mathrm{~g}$ (Figure 3d).

Stored seeds of Apeiba tibourbou (Aubl), glass and Kraft paper packagings did not increase the dry biomass of seedlings coming from seeds that were stored in the chamber up to 180 days 
(LORENZI; MATOS et al., 2008). Similarly for the seeds of E. velutina in this study, the most proper condition to preserve the seeds, with the lowest viability and vigor loss, was the natural laboratory environment, using both Kraft paper packaging and polyethylene bags.

More vigorous seeds originate seedlings with higher growth rates (GUEDES et al., 2009); this is related to the higher translocation of reserves of the storage tissues to the growth of the embryonic axis. However, the variations occurred during storage, mainly in the WC (MARCOS-FILHO, 2015).

Another variable that can be correlated with the decrease in seedling vigor is the seed size. According to Carvalho and Nakagawa (2012), seed size has no influence on germination, but affects the vigor of the resulting seedlings, with larger seeds giving rise to more vigorous seedlings and, in varying field conditions, may result in superior stands.

The results found in the growth of E. velutina seedlings show that even obtaining during storage a quicker germination or a germination equal or close to $100 \%$, with fluctuations in the WC, this did not mean success in the seedling vigor or higher growth and dry biomass can be correlated to the variations in WC.

\section{CONCLUSION}

Erytrhina velutina seeds stored at room temperature, in paper and plastic bags up to 420 days, maintain high physiological quality, this condition allowed to preserve the seeds, with the best viability (germination data) and lowest vigor loss (growth and dry biomass). Besides that, due to low requirement of special equipment or treatment these seeds can be easily stored by small farm seedling producers for more than a year without losing its viability.

\section{REFERENCES}

BALEŠEVIĆ-TUBIĆ, S.; TAÍC, M.; DORDEVIC, V.; NIKOLIC, Z.; DUKIC, V. Seed viability of oil crops depending on storage conditions. Helia, Serbia, v. 33, n. 52, p. 153-159. 2010. DOI: http://dx.doi.org/10.2298/hel1052153b.

BEWLEY, J. D.; BRADFOR, J. D.; HILHORST, H.; NONOGAKI, H. Longevity, storage, and deterioration. In: Seeds. Springer New York. 2013. p. 341-376.

BRASIL. Ministério da Agricultura e Reforma Agrária. Secretaria Nacional de defesa Agropecuária. Instruções para análise de sementes de espécies florestais. Brasília, 2013. 97 p.

BRASIL. Ministério da Agricultura, Pecuária e Abastecimento. Regras para análise de sementes. Ministério da Agricultura, Pecuária e Abastecimento. Secretaria de Defesa Agropecuária. Brasília: MAPA/ACS, 2009. 395 p.

CARDOSO, R. B.; BINOTTI, F. F. S.; CARDOSO, E. D. Potencial fisiológico de sementes de crambe em função de embalagens e armazenamento. Pesquisa Agropecuária Tropical, Goiânia, v.42, n.3, p.272-278, 2012. DOI: $10.1590 /$ S1983-40632012000300006

CARVALHO, N. M.; NAKAGAWA, J. Sementes: ciência, tecnologia e produção. 5.ed. Jaboticabal: FUNEP, 2012. $590 \mathrm{p}$.

FERREIRA, A. G.; BORGHETTI, F. (Eds). Germinação: do básico ao aplicado. Porto Alegre: Artmed, 2004. 323p.

GRAHAM, I. A. Seed storage oil mobilization. Annual Review of Plant Biology, v. 59, p. 115-142, 2008.

GUEDES, R. S.; ALVES, E. U.; GONÇALVES, E. P.; VIANNA, J. S.; FRANÇA, P. R. C.; SANTOS, S. S. Qualidade fisiológica de sementes armazenadas de Amburana cearensis (Allemao) AC Smith. Semina: Ciências Agrárias, Londrina, v.31, n.2, p.331-342, 2010. DOI: http://dx.doi.org/10.5433/1679-0359.2010v31n2p331

GUEDES, R. S; ALVES, E. U.; GONÇALVES, E. P.; SANTOS, S. R. N.; LIMA, C. R. Teste de comprimento de plântula na avaliação da qualidade fisiológica de sementes de Erythrina velutina Willd. Semina: Ciências Agrárias, Londrina, v.3, n.4, 793-802, 2009. DOI: http://dx.doi.org/10.5433/1679-0359.2009v30n4p793

HEYDECKER, W. Glossary of terms. In: HEYDECKER, W. (Ed.) Seed ecology. London, Butterworths, 1973. p.553-557.

Sci. For., Piracicaba, v. 46, n. 120, p. 562-570, dez. 2018

DOI: dx.doi.org/10.18671/scifor.v46n120.05 
Ribeiro et al. - Physiological quality of Erythrina velutina Willd. seeds

(FABACEAE) seeds under different storage conditions

KISSMANN, C.; SACLON, S. P. Q.; MUSSURY, R. M.; ROBAINA, A. D. Germinação e armazenamento de sementes de Albizia hasslerii (Chod.) Burkart. Revista Brasileira de Sementes, Londrina, v. 31, n. 2, p. 104-115, 2009.

KOTOWISKI, F. Temperature relations to germination of vegetable seeds. Proceedings of the American Society of Horticultural Science, Madison, v. 23, n.1, p.176-184, 1926.

LABOURIAU, L. G. A germinação das sementes. Washington: Secretaria da OEA, 1983. 173 p.

LORENZI, H.; MATOS, F. J. A. Plantas medicinais no Brasil: nativas e exóticas cultivadas. 2. ed. Nova Odessa: Instituto Plantarum, 2008. 544 p.

LUCIO, A. A.; ARAÚJO, M. N.; SILVA, F. F. S.; DANTAS, B. F. Effect of Storage in Different Environments and Packages on Germination of Amburana cearensis (Allemao) A. C. Sm. Seeds. International Journal of Environment, Agriculture and Biotechnology, v. 1, n. 4, p. 1037-1040, 2016. DOI: http://dx.doi.org/10.22161/ijeab/1.4.57

MAGUIRE, J. D. Speed of germination - aid in selection and evaluation for seedling emergence and vigor. Crop Science, v. 2, p. 176-177, 1962. DOI:10.2135/cropsci1962.0011183X000200020033x

MARCOS FILHO, J. Fisiologia de Sementes de Plantas Cultivadas. Piracicaba: FEALQ, 2015. 495p.

MATHEUS, M. T.; LOPES, J.C. Temperaturas cardinais para a germinação de Erythrina variegata L. Revista Brasileira de Sementes, Londrina, v. 31, n. 3, p. 115-122, 2009.

MELO, R. R.; CUNHA, M. C. L. Crescimento inicial de mudas de mulungu (Erythrina velutina Wild.) sob diferentes níveis de luminosidade. Ambiência Guarapuava, Paraná, v.4, n.1, p. 67-77, 2008.

NAKAGAWA J. Testes de vigor baseados no desempenho das plântulas. In: F. C. KRZYZANOWSKI, R. D. VIEIRA AND J. B. FRANÇA-NETO (eds.). Vigor de sementes: conceitos e testes. Londrina: ABRATES, 1999,218 p.

PARRELlA, N. N. L. D. Armazenamento de sementes. EPAMIG: MG, 2011. Disponível em: < http://www. epamig.br/index.php?option=com_docman\&task=download\&gid=1519 Acesso: 01 Abr. 2014.

PRITCHARD, H. W.; MOAT, J. F.; FERRAZ, J. B. S.; MARKS, T.; CAMARGO, J. L. C.; NADARAJAN, J.; FERRAZ, I. Innovative approaches to the preservation of forest trees. Forest Ecology and Management, v. 333, p. 88-98, 2014. DOI: https://doi.org/10.1016/j.foreco.2014.08.012

REIS, R. C. R; PELACANI, C. R.; ANTUNES, G. C.; DANTAS, B. F.; CASTRO, R. D. Physiological quality of Gliricidia sepium (Jacq.) Steud.(Leguminosae-Papilionoideae) seeds subjected to different storage conditions. Revista Árvore, Viçosa, v. 36, n. 2, p. 229-235. 2012. http://dx.doi.org/10.1590/S0100-67622012000200004

RIBEIRO, R. C.; DANTAS, B. F.; MATIAS, J. R.; PELACANIM C. R. Efeito do estresse salino na germinação e crescimento inicial de plântulas de Erythrina velutina Willd. (Fabaceae). Gaia Scientia, v. 11, n. 4, p. 65-78. 2017. DOI: http://dx.doi.org/ 10.21707/gs.v11.n04a08

SANTOS, F. S. D; PAULA, R. C.; SABONARO, D. Z.; VALADARES, J. Biometria e qualidade fisiológica de sementes de diferentes matrizes de Tabebuia chrysotricha (Mart. Ex A. DC.) Stand. Scientia Florestalis, Viçosa, v. 37, n. 82, p. 163-173, 2009. http://www.sifloresta.ufv.br/handle/123456789/16805

SILVA, F. A. S.; AZEVEDO, C. A. V. The Assistat Software Version 7.7 and its use in the analysis of experimental data. African Journal of Agricultural Research. v. 11, n. 39, p. 3733-3740, 2016. DOI: 10.5897/AJAR2016.11522

SILVA, K. B; ALVES, E. U.; GONÇALVES, E. P.; BRUNO, R. L. A.; FRANÇA, P. R. C. Armazenamento de sementes de Erythrina velutina Willd. Revista Árvore, Viçosa, v. 35, n.4, p.809-816, 2011. DOI: http://dx.doi.org/10.1590/ s0100-67622011000500006

Received: 30/08/2017

Accepted: 02/05/2018 